\title{
Evaluation of Lead Effects on Laccase Enzyme Activity in Bacillus Subtilis WPI
}

\author{
Parisa Mehrabi Moghadam ${ }^{\text {iD }}$, Hassan Mahmoudi $^{2^{*}}$ (D)
}

1. Departments of Biology, Faculty of Basic Sciences, Islamic Azad University, Hamadan Branch, Hamadan, Iran

2. Department of Microbiology, School of Medicine, Hamadan University of Medical Sciences, Hamadan, Iran.

\begin{tabular}{|c|c|}
\hline $\begin{array}{l}\text { Use your device to scan } \\
\text { and read the article online }\end{array}$ & \multirow[b]{2}{*}{$\begin{array}{l}\text { Citation Mehrabi Moghadam P, Mahmoudi H. Evaluation of Lead Effects on Laccase Enzyme Activity in Bacillus Subtilis } \\
\text { WPI. Research in Molecular Medicine. 2019; 7(2):19-24. https://doi.org/10.32598/rmm.7.2.69 }\end{array}$} \\
\hline 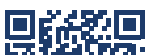 & \\
\hline Dritsing & doli https://doi.org/10.32598/rmm.7.2.69 \\
\hline
\end{tabular}

\section{(i) (s)}

Article Type:

Research Article

Article info:

Received: 15 Jan 2019

Revised: 05 Feb 2019

Accepted: 20 Feb 2019

Keywords:

Bacillus subtilis, laccase,

Lead, environmental

pollutants, Lead

\section{A B S T RA C T}

Background: Lead $(\mathrm{Pb})$ is an important environmental pollutants that play a significant role in increasing the stability of some other pollutants by changing the microbial profile of the soil. Bacillus subtilis WPI is an abundant bacteria existing in wastewater. Because of laccase enzyme in this bacterium, the decomposition process of aromatic pollutants in wastewaters can be facilitated. We aimed to investigate the effect of different $\mathrm{Pb}$ concentrations on $\mathrm{B}$. subtilis growth and biological activity of laccase enzyme in $B$. subtilis WPI.

Materials and Methods: B. subtilis WPI was isolated from the paper mill industrial wastewater of Hormozgan, Iran, from March to August 2017. After purification, the growth trend of $B$. subtilis WPI as well as the activity of laccase enzyme in different concentrations of $\mathrm{Pb}$ was investigated based on kinetic method.

Results: Bacterial growth at $\mathrm{Pb}$ concentration of $400 \mathrm{mg} / \mathrm{L}$ reduced in a dose-dependent manner, and this decrease was significant at concentrations of 300 and $400 \mathrm{mg} / \mathrm{L}(\mathrm{P}<0.001)$. The level of laccase enzyme activity in the lead concentration range of $20-160 \mathrm{mg} / \mathrm{L}$ also reduced in a dosedependent manner, which implied that the highest decrease was observed at lead concentration of $160 \mathrm{mg} / \mathrm{L}(\mathrm{P}<0.01)$. Our findings showed that there was no significant change in bacterial growth in lead concentration range of $20-200 \mathrm{mg} / \mathrm{L}$, while a significant change was observed in the activity of laccase enzyme in the mentioned concentration range.

Conclusion: Therefore, it seems that this reduction in enzyme activity can indirectly increase the stability of aromatic oil pollutants in the environment.

\section{Introduction}

urrently, urbanization and industrial development in human societies have led to an ever-increase of industrial pollutants in the environment [1]. Meanwhile, heavy metals, which are the most impor- tant environmental pollutants, in large quantities can cause a change in the balance of biological agents in the ecosystem [2]. The discharge of these elements into the environment is much higher than that produced through natural processes. Lead $(\mathrm{Pb})$ as one of the most toxic elements that enter the environment through various industries, such as petrochemicals, battery pro-

* Corresponding Author:

Hassan Mahmoudi, PhD.

Address: Department of Microbiology, School of Medicine, Hamadan University of Medical Sciences, Hamadan, Iran.

Phone: +98 (918) 9539458

E-mail: umsha16@gmail.com 
duction, crystallization, mining, lead processing, and mainly burning of fossil fuels. Lead is a metal without biological function $[3,4]$.

This element not only threatens human health but can also change the microbial profile of the ecosystem [5]. The increased environmental sustainability of aromatic pollutants in petroleum products can be considered due to the microbial profile change. Because of the presence of heavy metal-resistance systems and degrading enzymes for aromatic compounds in some bacteria, the bacteria have received more attention compared to other microorganisms. The metal resistance systems have been identified in many bacterial groups B. subtilis is one of the most abundant bacteria in wastewater that can play a valuable role in the ecosystem. Previous studies reported that laccase enzyme affects the nature of $B$. Subtilis WPI [6].

The large distribution of this enzyme in this bacterium has converted it to an important indicator of environmental degradation $[7,8]$. The laccase enzyme is a polyphenol oxidase, containing several copper atoms and has been found in many plants, fungi, insects, and microorganisms $[8,9]$. Due to the environmental and economic advantages of this enzyme and the role of B. subtilis in its production, it was used for degrading aromatic pollutants in wastewaters [10]. In this study, we investigated the effects of various lead concentrations on the growth of B. subtilis WPI and the biological activity of laccase enzyme in B. subtilis WPI.

\section{Materials and Methods}

\section{Sampling and isolation of Bacillus subtilis WPI}

B. subtilis WPI was isolated from the paper mill industrial wastewater of Hormozgan, Iran, from March to August 2017. Briefly, after sampling the soil, bagasse and wastewater of the paper mill were collected from the ground of $10-15 \mathrm{~cm}$ soil depth in sterile plastic bags and were kept at $4^{\circ} \mathrm{C}$ [11-13]. To isolate the bacteria, $10 \mathrm{~g}$ of the sample was transferred to a $250 \mathrm{~mL}$ flask and mixed with $100 \mathrm{~mL}$ of sterile saline solution. Next, after the preparation of serial dilutions (range 10-1 - 10-9) and spared culture on a nutrient agar plate (Merck, Germany), bacterial colonies were screened at the surface of the agar plate containing $0.5 \mathrm{mM}$ guaiacol to determine the laccase enzyme activity.

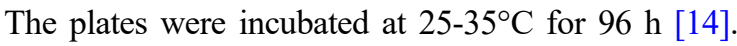
The isolation and screening methods were used several times to obtain a pure specimen that produces only one strain containing laccase enzymes. By considering physiological and biochemical properties, the morphology of the strain that produces the laccase enzyme was studied.
Biochemical tests were performed to detect B. subtilis bacteria including oxidase, catalase, amylase, mannitol, lactose, glucose, citrate, xylose, and sucrose [12].

\section{Determining bacterial growth at different times}

First, bacterial suspension was performed according to the half-McFarland standard (equal to $1.5 \times 108$ colony forming units (CFU / $\mathrm{mL}$ ) and was inoculated into $20 \mathrm{~mL}$ of Tryptic Soy Broth (TSB). Next, the samples were incubated in a shaker incubator at $37^{\circ} \mathrm{C}$. The bacterial growth assay was investigated at various times (from 1 to 10 days) using a spectrophotometer at a wavelength of $600 \mathrm{~nm}$ [15]

Optimization of growth conditions of B. subtilis bacteria in TSB medium

The effects of temperature, growth time, and different concentrations of Copper $(\mathrm{Cu})$ as a co-factor required for bactericidal activity and production of laccase enzyme were investigated.

\section{Bacterial growth rate at different temperature}

The bacterial growth capability was investigated at temperatures of $25^{\circ} \mathrm{C}, 30^{\circ} \mathrm{C}, 35^{\circ} \mathrm{C}, 40^{\circ} \mathrm{C}$, and $45^{\circ} \mathrm{C}$. The bacteria growth was measured over a period of 5 days using a spectrophotometer at a wavelength of $600 \mathrm{~nm}$ [15].

\section{Optimizing laccase enzyme activity}

The concentration of copper sulfate in the environment is another factor affecting the growth, activity, and production of laccase enzymes in B. subtilis bacteria [16, 17]. Therefore, different concentrations of copper sulfate $\left(\mathrm{CuSO}_{4}\right)(0.1 \mathrm{mM}, 0.2 \mathrm{mM}, 0.3 \mathrm{mM}, 0.4 \mathrm{mM}$, and 0.5 $\mathrm{mM}$ ) and control sample (without adding copper sulfate) were incubated for five days. The activity rate of the laccase enzyme at these concentrations was measured at 436 $\mathrm{nm}$ wavelength using two measurements of the optical absorbance over three minutes interval with 2, 2-azino-bis (3- ethylbenzothiazoline- 6-sulfonic acid) Sigma-Aldirich (ABTS) substrate. Eventually, the enzyme activity was determined in accordance with the following equation [18].

Enzyme activity rate $=$ Optical Density $(O D) \times 60 \times($ enzyme value $/ 1150) \times 0.371$

Effect of different concentrations of lead on the growth of B. subtilis WPI

To obtain the optimum concentration of lead $\mathrm{Pb}\left(\mathrm{No}_{3}{ }^{2}\right)$, the effects of this metal at concentration range of 40-400 $\mathrm{mg} / \mathrm{L}$ on the growth process of B. subtilis bacteria were 
evaluated. Briefly, $1 \mathrm{ml}$ of bacteria suspension was incubated in $20 \mathrm{~mL}$ of TSB medium containing $40 \mathrm{mg} / \mathrm{L}$, $100 \mathrm{mg} / \mathrm{L}, 200 \mathrm{mg} / \mathrm{L}, 300 \mathrm{mg} / \mathrm{L}$, and $400 \mathrm{mg} / \mathrm{L}$ of lead. Moreover, non- $\mathrm{Pb}$ containing medium was used as the control. All of the mediums were kept in a shaker incubator at $150 \mathrm{rpm}$ and a temperature of $35^{\circ} \mathrm{C}$ and their OD was measured at a wavelength of $600 \mathrm{~nm}$ for five days.

Effect of different concentrations of lead $(\mathrm{Pb})$ on laccase activity

The lead concentrations of $160 \mathrm{mg} / \mathrm{L}, 80 \mathrm{mg} / \mathrm{L}, 40$ $\mathrm{mg} / \mathrm{L}$, and $20 \mathrm{mg} / \mathrm{L}$ were introduced into bacterial culture medium and the activity of laccase enzyme was measured daily for five days. Based on the results of microbial culture, there was no change in the growth rate of the bacteria at concentration range of $20-160 \mathrm{mg} / \mathrm{L}$.

\section{Statistical analysis}

All experiments were performed in triplicates, and the data analyzed using the variance (ANOVA) followed by the Tukey's test in SPSS V. 21. All the results are expressed as Mean \pm SD. The level of significance was defined as P-values less than 0.05 .

\section{Results}

\section{Identification of B. subtilis WPI}

The results obtained from the biochemical tests were for the identification and confirmation of B. subtilis WPI.

\section{Optimal conditions for bacterial growth}

The results obtained for $B$. subtilis WPI growth within 10 days of incubation indicated that the highest and lowest growth rates on 5 and 10 days were $2.6 \times 10^{4}$ and $0.73 \times 10^{4} \mathrm{CFU} / \mathrm{mL}$, respectively (Figure $1 \mathrm{~A}$ ). Moreover, this bacterium had the best growth rate at $35^{\circ} \mathrm{C}$ and the highest light absorption at this temperature was 0.35 . The lowest growth rate was observed at $25^{\circ} \mathrm{C}$ and was 0.21 . As shown in, Figure $1 \mathrm{~B}$ there was a significant difference in the maximum bacterial growth between 25 $35^{\circ} \mathrm{C}(\mathrm{P}<0.05)$.

Effects of different concentrations of lead metal on the growth of $\mathrm{B}$. subtilis bacteria

As shown in Figure 2, there was no significant change in the bacterial growth at the lead concentration range of $20-200 \mathrm{mg} / \mathrm{L}$. However, at lead concentrations of 300 and $400 \mathrm{mg} / \mathrm{L}$, the bacterial growth rate significantly decreased compared to the control $(\mathrm{P}<0.001)$.

Effects of different concentrations of lead metal on the activity of laccase enzyme in B. subtilis

The activity of the laccase enzyme was evaluated in a safe dose range of lead (20-200 mg/L). As shown in Figure 3, with increasing lead concentration (within the concentration range mentioned above), the activity of the laccase enzyme decreased in a concentration dosemanner, and this decrease was significant at concentrations of 80 and $160 \mathrm{mg} / \mathrm{L}(\mathrm{P}<0.001)$. Effect of various copper sulfate $\left(\mathrm{CuSO}_{4}\right)$ concentrations on the production of laccase enzymes.

Our findings showed that there was a significant difference in the activity level of laccase enzyme in $0.2 \mathrm{mM}$ of copper sulfate compared to the control $(\mathrm{P}<0.001)$. Therefore, this amount $(0.2 \mathrm{mM})$ of copper sulfate was chosen as the optimum concentration for the study of laccase enzyme activity (Figure 4$)(\mathrm{P}<0.001)$.
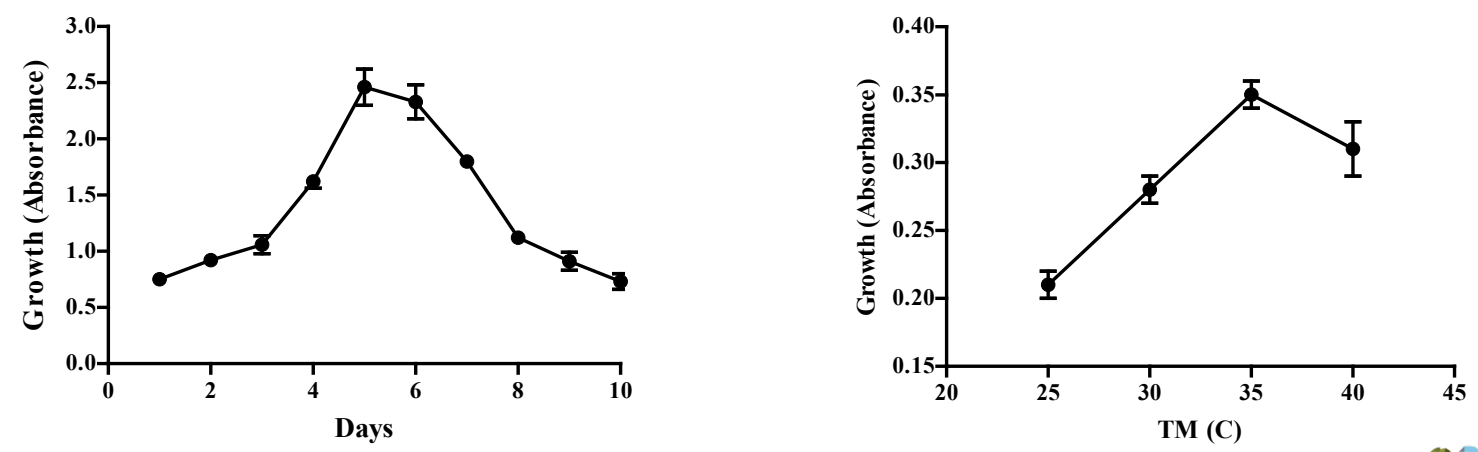

Figure 1. A: Measuring growth kinetics of B. subtilis WPI during 10 days of incubation at $600 \mathrm{~nm}$ measurements; B: Measuring growth kinetics of $B$. subtilis WPI at various temperatures 


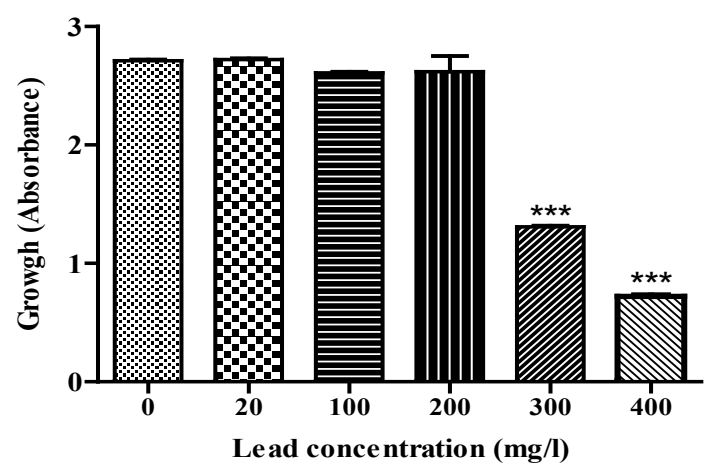

grmm

Figure 2. Growth changes in B. subtilis after five days of exposure to different lead concentrations

\section{Discussion}

The temperature is an effective factor for inducing and/ or inhibiting enzymatic reactions participating in bacterial growth [19-20]. In the current study, the reduction of bacterial growth rate at $40^{\circ} \mathrm{C}$ can be due to the loss of metabolic activity of the cell, and subsequent delay in the bacterial division. In the study of Shukur et al. $35^{\circ} \mathrm{C}$ was reported as the optimal temperature for the growth of B. Subtilis, and this is in agreement with our findings [21]. However, in another study, the highest activity of the laccase in B. subtilis WD 23 was observed at $25^{\circ} \mathrm{C}$ [22].

Bacillus species were identified as the most abundant gram-positive bacteria in the soil and were used for the study of laccase enzyme activity under optimum conditions. Meanwhile, copper is one of the most important factors affecting the production and activity of laccase enzyme. In the present study, the optimum concentration of copper to induce laccase activity was determined to be $0.2 \mathrm{mM}$. In line with our findings, a similar study on

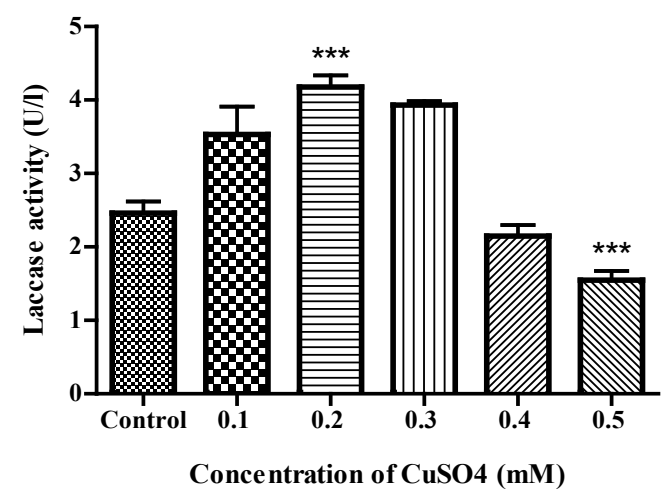

grmm

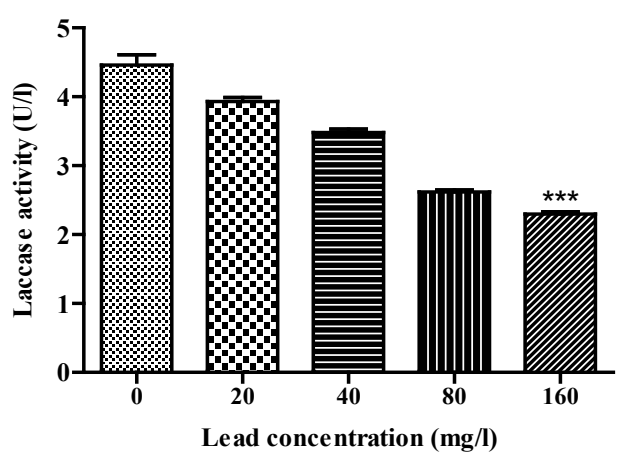

grmm

Figure 3. Changes in the activity of laccase enzyme in B. subtilis after five days of exposure to different lead concentrations

the effect of different concentrations of copper sulfate on the growth of $B$. subtilis WPI showed that $0.2 \mathrm{mM}$ of this compound was chosen as the optimum concentration for stimulating laccase enzyme activity [23].

Moreover, Shukur et al. in their study on Bacillus B16 showed that $0.2 \mathrm{Mm}$ of copper sulfate could stimulate the production of spore laccase enzyme and increase its amount to $6.6 \mathrm{Unit} / \mathrm{mL}$ [21]. Regardless of the bacterial species, the laccase enzyme appears to have kinetically similar responses to copper, which may be due to the structural similarity of the enzyme in different species of B. subtilis bacteria, and this plays an important role in the degradation of aromatic pollutants in petroleum products [24].

Based on the results of Logascus et al. this bacterium has a relative resistance to $\mathrm{Pb}$ exposure [25]. Our findings demonstrated that there was no significant decrease in the growth of this bacterium at the concentration range of 20-200 $\mathrm{mg} / \mathrm{L}$. The resistance of B. subtilis bacteria to $\mathrm{Pb}$ exposure in the abovementioned concentration range may be attributed to the collaboration of PbrA transfer protein and $\mathrm{PbB}$ phosphatase enzyme, which increases the resistance of this bacterium to $\mathrm{Pb}$ exposure [26]. This can lead to the formation of Pb-resistant species in the ecosystem. Concerning this, Zhang et al. showed that $\mathrm{Pb}$-resistant strains in $\mathrm{Pb}$-contaminated soils increased compared to uncontaminated soils [27]. However, bacterial growth significantly reduced at $\mathrm{Pb}$ concentrations higher than $200 \mathrm{mg} / \mathrm{L}$, which may be attributed to sudden shock and lack of sufficient opportunity to adapt to $\mathrm{Pb}$ exposure at high concentrations. Laccase is a polyphenol oxidase containing several copper atoms [28].

Figure 4. The activity of laccase enzyme in B. subtilis WPI at different concentrations of copper 


\section{Conclusion}

The results of this study indicated that heavy $\mathrm{Pb}$ metal at concentrations above $20 \mathrm{mg} / \mathrm{L}$ had a decreasing trend on the activity of laccase enzymes in $B$. subtilis WPI, and increasing $\mathrm{Pb}$ concentration to $160 \mathrm{mg} / \mathrm{L}$, laccase activity rate was reduced by half in the samples compared to the controls. Therefore, releasing these metals into the industrial wastewater, such as paper mills, which is a main source of $B$. subtilis WPI, will not only eliminate this strain in the ecosystem but also reduces laccase enzyme activity causing the sustainability of other pollutants in the environment.

One of the most important limitations of this study was the preparation of $B$. subtilis WPI.

\section{Ethical Considerations}

\section{Compliance with ethical guidelines}

All ethical principles were considered in this article.

\section{Funding}

This research did not receive any specific grant from funding agencies in the public, commercial, or not-forprofit sectors.

\section{Authors contribution}

Designing the experiments, writing the manuscript, conducting the experiment and data analysis, participating in the initial draft, revision of the manuscript, reading and approving the final manuscript: Parisa Mehrabi Moghadam, Hassan Mahmoudi.

\section{Conflict of interest}

The authors declared no conflict of interests

Acknowledgement

Thank all my colleagues who assisted us with this project.

\section{References}

[1] Buragohain M, Bhuyan B, Sarma HP. Seasonal variations of lead, arsenic, cadmium and aluminium contamination of groundwater in Dhemaji district, Assam, India. Environmental Monitoring and Assessment. 2010; 170(1-4):345-51. [DOI:10.1007/s10661-009-1237-6] [PMID]
[2] Wang C, Zhao M, Lu L, Wei X, Li T. Characterization of spore laccase from Bacillus subtilis WD23 and its use in dye decolorization. Afr J Biotechnol. 2011; 10(11):2186-92.

[3] Oroojalian F, Kasra-Kermanshahi R, Azizi M, Bassami MR. Phytochemical composition of the essential oils from three Apiaceae species and their antibacterial effects on food-borne pathogens. Food Chem. 2010; 120(3):765-70. [DOI:10.1016/j. foodchem.2009.11.008]

[4] Makhlough A, Shokrzadeh M, Shaliji M, Abedi S. Comparative analysis of serum levels of aluminum and lead in dialysis patients, pre and post dialysis. Research Mol Med (RMM). 2014; 2(2):45-4. [DOI:10.18869/acadpub.rmm.2.2.45]

[5] Ahalya N, Ramachandra T, Kanamadi R. Biosorption of heavy metals. Res J Chem Environ. 2003; 7(4):71-9.

[6] Ruijssenaars H, Hartmans S. A cloned Bacillus halodurans multicopper oxidase exhibiting alkaline laccase activity. Appl Microbiol Biotechnol. 2004; 65(2):177-82. [DOI:10.1007/ s00253-004-1571-0] [PMID]

[7] Endo K, Hayashi Y, Hibi T, Hosono K, Beppu T, Ueda K. Enzymological characterization of EpoA, a laccase-like phenol oxidase produced by Streptomyces griseus. J Biochem. 2003 133(5):671-7. [DOI:10.1093/jb/mvg086] [PMID]

[8] Koschorreck K, Schmid RD, Urlacher VB. Improving the functional expression of a Bacillus licheniformis laccase by random and site-directed mutagenesis. BMC Biotechnol. 2009; 9(1):12. [DOI:10.1186/1472-6750-9-12] [PMID] [PMCID]

[9] Shraddha, Shekher R, Sehgal S, Kamthania M, Kumar A. Laccase: Microbial sources, production, purification, and potential biotechnological applications. Enzyme Res. 2011; 2011:111. [DOI:10.4061/2011/217861] [PMID] [PMCID]

[10] Pazarlıoğlu NK, Sariişik M, Telefoncu A. Laccase: Production by Trametes versicolor and application to denim washing. Process Biochem. 2005; 40(5):1673-8. [DOI:10.1016/j. procbio.2004.06.052]

[11] Xu F. Applications of oxidoreductases: Recent progress. Ind Biotechnol. 2005; 1(1):38-50. [DOI:10.1089/ind.2005.1.38]

[12] Saleh F, Kheirandish F, Azizi H, Azizi M. Molecular diagnosis and characterization of bacillus subtilis isolated from burn wound in Iran. Res Mol Med (RMM). 2014; 2(2):40-44. [DOI:10.18869/acadpub.rmm.2.2.40]

[13] Dalfard AB, Khajeh K, Soudi MR, Naderi-Manesh H, Ranjbar B, Sajedi RH. Isolation and biochemical characterization of laccase and tyrosinase activities in a novel melanogenic soil bacterium. Enzyme Microb Technol. 2006; 39(7):1409-16. [DOI:10.1016/j.enzmictec.2006.03.029]

[14] Bains J, Capalash N, Sharma P. Laccase from a non-melanogenic, alkalotolerant $\gamma$-proteobacterium JB isolated from industrial wastewater drained soil. Biotechnol Lett. 2003; 25(14):1155-9. [DOI:10.1023/ A:1024569722413] [PMID]

[15] Shirdam R, Khanafari A, Tabatabaee A. Cadmium, nickel and vanadium accumulation by three strains of marine bacteria. Iran J Biotechnol. 2006; 4(3):180-7.

[16] Wang $\mathrm{Cl}$, Zhao $\mathrm{M}$, Li Db, Cui DZ, Lu L, Wei Xd. Isolation and characterization of a novel bacillus subtilis WD23 exhibiting laccase activity from forest soil. Afr J Biotechnol. 2010; 113-116:7259. [DOI:10.4028/www.scientific.net/AMR.113-116.725] 
[17] Hullo MF, Moszer I, Danchin A, Martin-Verstraete I. CotA of Bacillus subtilis is a copper-dependent laccase. J Bacteriol. 2001; 183(18):5426-30. [DOI:10.1128/JB.183.18.54265430.2001] [PMID] [PMCID]

[18] Baldrian P, Gabriel J. Copper and cadmium increase laccase activity in Pleurotus ostreatus. FEMS Microbiol Lett. 2002; 206(1):19-24. [DOI:10.1111/j.1574-6968.2002.tb10988.x] [PMID]

[19] Niku-Paavola ML, Karhunen E, Salola P, Raunio V. Ligninolytic enzymes of the white-rot fungus Phlebia radiata. Biochem J. 1988; 254(3):877-84. [DOI:10.1042/bj2540877] [PMID] [PMCID]

[20] Cooper VS, Bennett AF, Lenski RE. Evolution of thermal dependence of growth rate of Escherichia coli populations during 20,000 generations in a constant environment. Evolution. 2001; 55(5):889-96. [DOI:10.1111/j.0014-3820.2001. tb00606.x]

[21] Shukur YN. Determination of optimal conditions for the production of laccase enzyme by local isolate of bacillus $\mathrm{sp}$. Iraqi J Sci. 2015; 56(1A):132-9.

[22] Wang J, Chen C. Biosorbents for heavy metals removal and their future. Biotechnol Adv. 2009; 27(2):195-226. [DOI:10.1016/j.biotechadv.2008.11.002] [PMID]

[23] Sheikhi F, Roayaei Ardakani M, Enayatzamir N, Ghezelbash GH. Isolation and identification of two laccase producer fungi from bagass and sugarcane rhizosphere. Mol Cell Res J. 2014; 27(3):389-98.

[24] Couto SR, Herrera L. Inhibitors of laccases: A review. Curr Enzym Inhib. 2006; 2(4):343-52. [DOI:10.2174/157340806778 699262]

[25] Lugauskas A, Levinskaitë L, Peèiulytë D, Repeèkienë J, Motuzas A, Vaisvalavièius R, et al. Effect of copper, zinc and lead acetates on microorganisms in soil. Ekologija. 2005; 1:61-9.

[26] Couto SR, Sanromán M, Gübitz G. Influence of redox mediators and metal ions on synthetic acid dye decolourization by crude laccase from Trametes hirsuta. Chemosphere. 2005; 58(4):417-22. [DOI:10.1016/j.chemosphere.2004.09.033] [PMID]

[27] Zhang HB, Yang MX, Shi W, Zheng Y, Sha T, Zhao ZW. Bacterial diversity in mine tailings compared by cultivation and cultivation-independent methods and their resistance to lead and cadmium. Microb Ecol. 2007; 54(4):705-12. [DOI:10.1007/s00248-007-9229-y] [PMID]

[28] Mayer AM, Staples RC. Laccase: New functions for an old enzyme. Phytochemistry. 2002; 60(6):551-65. [DOI:10.1016/ S0031-9422(02)00171-1] 